\title{
Evaluation of Different Biodegradable Polymers of Vegetable Origin Ace Fruit Edible Coatings for Prolonging Conservation
}

\author{
Jose Vicente Villarroel Bastidas ${ }^{1 *}$, Ana Jessenia Yanez, Cesar Ramiro Bermeo, Luis Tarquino Llerena, \\ Moises Menace Almea ${ }^{1}$, Robert Moreira Macias ${ }^{1}$ \\ ${ }^{1}$ Facultad de Ciencias de la Ingeniería, Universidad Técnica Estatal de Quevedo (UTEQ), Quevedo, Los Ríos EC.120501, Ecuador \\ ${ }^{2}$ Facultad de Ciencias Agrarias, Universidad Técnica Estatal de Quevedo (UTEQ), Quevedo, Los Ríos EC.120501, Ecuador \\ *Corresponding Author: José Vicente Villarroel Bastidas \\ E-mail: jvillarroel@uteq.edu.ec
}

\begin{abstract}
This investigation studies the effect that have the biodegradable polymers Starch of yuca and Protein of soya used like edible coatings in fruits with distinct morphological characteristics like Averrhoa carambolo L. (carambola), Carica papayaL. (Papaya) and Carica pentagona $\mathrm{H}$. (babaco). The experimental model used was a design of complete blocks at random with a factorial arrangement AxBxC equal to twelve treatments with two repetitions giving a total of twenty-four experimental units. The factors of study were: like factor To the types of fruits (Carambola, Papaya and Babaco), factor B states of maturity (semimaduro and mature) and like factor $C$ concentration of the coating (Starch of yuca and Protein of soya). To evaluate the effects of the coatings in the fruits analysed the following variables of study: ${ }^{\circ}$ Brix, $p H$, Acidity, Loss of weight and Colorimetry in $L^{*}, a^{*}$ and $b^{*}$. For the essays used fruits selected that you find free of impurities and mechanical damages, proceeded to the wash and disinfection in a solution of citrus acid to $2 \%$ during 20 minutes and produced the dried, afterwards prepared the coating forming a mix that heated to $60^{\circ} \mathrm{C} \mathrm{by} 30 \mathrm{~min}$ to $300 \mathrm{rpm}$ by means of a platen of magnetic agitation con warming, made the application of the coatings in the fruits by means of a paintbrush, the dried of the fruit made it to him to a temperature between $22{ }^{\circ} \mathrm{C}$ and $23^{\circ} \mathrm{C}$ for finally observe the process of maduration of each one of the fruits. The results indicate that by means of the application of the coating to base of the polymer starch of yuca in carambolas attained to prolong the useful life and conservation of this fruit.
\end{abstract}

Keywords: Maduration, breath, transpiration, ${ }^{\circ}$ Brix

\section{Introduction}

An edible coating defines like a continuous matrix, thin that structures around the food generally by means of the immersion of the same in a solution formadora of the coating, these solutions formadoras of coatings can be conformed by a polysaccharide, a compound of proteinaceous nature, lipídica or by a mix of the same (Quintero, 2010).

The carambola, papaya and the babaco are fruits that follow his process of maduration even after the harvest by what are climatéricas, increasing his tax of breath and production of etileno, in which mediante this investigation looks for prolong the time of conservation implementing edible coatings that help to improve the texture and the quality in the storage.

For the preparation of this coating used two types of biodegradable polymers as they are the starch of yuca and the protein of soya in which they combined with oil of olive and antioxidant as to the citrus acid, the same that they will be applied to the fruits of manual form with the help of a paintbrush forming coatings that help to reduce the maduration and prolong his useful life.

The coatings have developed with the end to extend the useful life of the alimentary products, use like support of antimicrobic agents, antioxidant or nutrients, for enlentecer the migration of humidity and lipids or the transport of gases and solutes.
In products hortofrutícolas, like the mango and the avocado, can employ like barrier to gases and steam of water, for this purpose apply on the surface of the food with the paramount function to restrict the loss of humidity of the fruit to the environment, reduce the absorption of Or2 to diminish his respiratory tax, increase his useful life and reduce the losses post cosecha (Quintero, 2010). This investigation studied the prolongation of the useful life of this type of fruits with the application of polymers as his maduration is accelerated.

\section{Materials and Methods}

The physical analyses and chemists were made with the materials and available teams in the basic laboratory of Chemistry and of the laboratory of Biotechnology of the State Technical University of Quevedo ( $79^{\circ} 28^{\prime} 30^{\prime}$ "West, $1^{\circ}$ $\left.6^{\prime} \mathrm{S}\right)$. It applied a factorial design of Blocks Entirely at random $(A * B * C)$ like Factor To (Types of fruits), Factor $B$ (states of maturity) and Factor $\mathrm{C}$ (types of coatings).The prime matter recolecto of the zone of Quevedo whose location is Latitude: $1^{\circ} 02^{\prime} 00^{\prime \prime} \mathrm{S}$ Length: $79^{\circ} 27^{\prime} 00^{\prime \prime}$ Or that belongs to the province of The Rivers. The analyses effected in duplicate in each treatment.

Coating of polymers for the conservation of the fruits.

Recolectaron 25 units of carambola with a weight average of $45,37 \mathrm{~g}, 25$ units of papaya hawaiana with a weight average of 483, $46 \mathrm{~g}$ and 25 units of babaco with an approximate weight of $1255,13 \mathrm{~g}$, eachone of them in statesemimaduro 


\section{International Journal of Science and Research (IJSR) \\ ISSN (Online) : 2319-7064}

Index Copernicus Value (2015) : 78.96 | Impact Factor (2015) : 6.391

and mature. They selected in good condition fruits that do not present mechanical damages neither magulladuras. The fruits selected washed with drinkable water, in which it proceeded to the immersion in a solution of citrus acid to $2 \%$ during 20 minutes. The fruits dried during 1 hour to temperature acclimatise. The coatings elaborated to base of polymers Starch of yuca to $8 \%(16 \mathrm{~g})$ in the same quantities applied in the coating with Protein of soya to $8 \%$ (16 g) used sour citrus like antioxidant to $0,05 \%(0,1 \mathrm{~g})$ and oil of olive to $70 \%(140 \mathrm{ml})$, the mix heated to $60^{\circ} \mathrm{C}$ by 30 min to $300 \mathrm{rpm}$ by means of a platen of magnetic agitation with warming, used a paintbrush for the application of the coatings, which proceeded to recubrir the fruits creating layers and afterwards left dry to temperature acclimatise.

\section{Physical analysis-Chemical and Microbiological}

To determine the $\mathrm{pH}$ used a potentiometer in reference to the Ecuadorian Technical Norm 1529; Been used to soluble by means of a refractómetro, of agreement to the Ecuadorian Technical Norm 2 337; acidity titulable effected it to him of agreement to the method based in a degree with $\mathrm{NaOH} 0,1$ Normal, of agreement to the Ecuadorian Technical Norm 0381; the analysis of colorimetry ( $\mathrm{L}^{*} \mathrm{a}^{*} \mathrm{~b}^{*}$ ) made it to him using a colorimeter COLOUR ANALYZER RGB-1002; As lace losses of weight determined by gravimetry by means of the difference between weights in which it takes the initial weight $(\mathrm{Pi})$ less the weight of the fruit at the end (Pf) of the storage and the results expressed like percentage of loss of weight $(\% \mathrm{PP})$ by means of the following equation:

$$
\% P P=\frac{\left(P_{i}-P_{f}\right)}{P_{i}}
$$

\section{Statistical analysis}

For the analysis of data made proofs of normality and homogeneity of variance using the proofs of KolmogorovSmirnov and Levene, respectively. It used an ANOVA to determine the statistical differences between the variables measured in the experiment. Finalmente made the proof post hoc of comparison of ranks multiples HDS Tukey. SAnd fixed a level of significancia of $<P 0$, 5. The statistical analyses made with the statistical program StatGraphics v. 16.1.

\section{Results and Discussion}

\section{Types of fruits (Carambola, Papaya Hawaiana, Babaco)}

Regarding the Factor To (types of fruits), determined values of ${ }^{\circ}$ Brix in $\mathrm{a}_{0}$ (carambola) $=5,6 ; \mathrm{a}_{1}$ (papaya) $=12,22$ and $\mathrm{a}_{2}$ (babaco) $=5,725$ the carambola ison the 1,25 posedby the Norm INEN 2337 (Juices, Pulps, Concentrated, Drunk of fruits and vegetal Requirements-2008), because of the state of maturity that obtained during the time of storage, the papaya the valuefindson $11,58 \pm 0,93$ reportedby (Miranda,

2014) in his study Andfectos of two coatings on the quality of the papaya ( ) variety Tainung, which indicates that the fruit climatérico follows a process of maduration since his breath increases, in the babaco the value is upper to 5, 0 that indicates the NormINEN 2337 (Juices, Pulps, Concentrated, Drunk of fruits and vegetal
Requirements-2008) since the time of storage there was not variation in his maduration.

In what it concerns to $\mathrm{pH}$ in $\mathrm{a}_{0}$ (carambola) $=3,81875 \mathrm{a}_{1}$ (papaya) $=5,47625$ and $\mathrm{a}_{2}$ (babaco) $=4,3875$ in carambola the value finds upper to 3, 44 of the reported by (Narain,

2011) in his study physical and chemical Composition of the fruit carambola (

In three states of maturity this wants to say that during the time of storage increased the $\mathrm{pH}$ when increasing his maduration, in the papaya and babaco the value is similar to $5,3 \pm 0,04$ what does reference (Miranda, 2014) by action of the present acids in each one of the fruits in study in this case the acid málico acts in function to the degree of maturity in each one of the fruits.

Andn the aciditya $_{0}($ carambola $)=0,27375 ; a_{1}($ papaya $)=0$, 089625 and $\mathrm{a}_{2}$ (babaco) $=0$, 46in the carambola the value finds inferior to 1, 48 to the reported by (Hernández, 2004) in the investigation Aprovechamiento integral of the fruit of Carambolo (

The difference presents for finding the fruit in a process of physiological development of change of maturity of semimadura to mature altering the acidity of each one of the fruits studied, in the papayathe value finds underneath of $0,097 \pm 0,004$ in the established by (Miranda, 2014) in his study Andfectos of two coatings on the quality of the papaya (

variety Tainung gives like result that the transpiration and the breath has retardado by effect of the coatings, in the babaco obtained a value of $0,040-0,050$ regarding the Norm INEN 1 998:2005 Cool Fruits. Babaco. Requirements debido to that the fruits find in state semimaduro affirming that the coatings actuarum like preservatives and avoided the transpiration and breath of each one of the fruits.

In pérdidaof weight $\mathrm{a}_{0}$ (carambola) $=6,77875 ;$ to $_{1}$ (papaya) $=5,74$ and $\mathrm{a}_{2}$ (babaco) $=4,6425$ in the carambola, papaya and the babaco the value finds underneath of $9,54 \pm 0,10$ reported by Miranda, 2014) in his study Andfectos of two coatings on the quality of the papaya (

variety Tainung this wants to say that the coating of polymers applied presented a progressive decrease of the percentage of loss of weight along the days of the storage.

Regarding the evolution of the colorimetric coordinates CIE-L* $a^{*} b^{*}$, in the coordinate $L^{*}$ (luminance), $a_{0}$ (carambola) $=41,0648 ; a_{1}$ (papaya) $=66,1672$ and $a_{2}$ $($ babaco $)=53,0121$ the fruits studied presented lower values to 88, 08 those that does reference (Camacho, 2012) in the investigacion Determinación of the colour of the exocarpio like indicator of physiological development and maturity in the guava pear ( . Guava pear), using technical of digital processing of images, this indicates that the fruits presented a tendency in the skin to clear colours to measure that advanced the maduration.

$L^{*}$ coordinate $a^{*}$ (variation of red colour-green) $a_{0}$ (carambola) $=-0,4277 ; t_{1}$ (papaya) $=-11$, 596and $a_{2}$ (babaco) $=-14,4598$ the carambola obtained a value that finds with -7, 76 indicates that the fruit andvoluciono of near negative values to zero, by what the green tonality kept by effect of the coating, instead in the papaya and the babaco the values found upper that in what it establishes (Camacho, 


\section{International Journal of Science and Research (IJSR) \\ ISSN (Online) : 2319-7064}

Index Copernicus Value (2015) : 78.96 | Impact Factor (2015) : 6.391

, 2012) in the investigacion Determinación of the colour of the exocarpio like indicator of physiological development and maturity in the guava pear (

. Guava pear), using technical of digital processing of images, by what had a gradual decrease of the cgreen smell by maturity of the fruits during the time of storage.
Lto coordinate $b^{*}$ (variation of the yellow colour-blue) ) $a_{0}$ (carambola) $=14,607 ; a_{1}$ (papaya) $=41,8373$ and $a_{2}$ (babaco) $=37,4987$ in the carambola observed an inferior value on the yellow tonality since by effect of the coating kept a green tonality, instead in the papaya and the babaco presented increase to the yellow since they obtained similar values to 52, 76 in the reported by (Camacho, ,2012) in the investigacion.

\begin{tabular}{|c|c|c|c|c|c|c|c|}
\hline Factor To & Brix & PH & Acidity & Loss of weight & $\mathrm{L}^{*}$ & $\mathrm{a}^{*}$ & $\mathrm{~b}^{*}$ \\
\hline Carambola & 5,6 & 3,81875 & 0,27375 & 6,77875 & 41,0648 & $-0,4277$ & 14,607 \\
\hline Papaya & 12,225 & 5,47625 & 0,089625 & 5,74 & 66,1672 & $-11,596$ & 41,8373 \\
\hline Babaco & 5,725 & 4,3875 & 0,46 & 4,6425 & 53,0121 & $-14,4598$ & 37,4987 \\
\hline
\end{tabular}

\section{States of maturity (semimaduro and mature)}

In the Factor B (States of maturity), determined values of ${ }^{\circ}$ Brix in $\mathrm{b}_{0}$ (semimaduro) $=7,65$ and $b_{1}$ (mature) $=8,05$, in carambola semimadura 7, $30 \pm 1,01$ and mature $10,83 \mathrm{~b} \pm 0$, 29posedby (Narain, , 2011) in his study physical and chemical Composition of the fruit carambola (

.) That in three states of maturity, which indicates that in the states studied existed a slight increase of ${ }^{\circ}$ Brix since it did not initiate the senescencia of the fruit during the storage by the action of the coatings, in the papaya semimadura $11,53 \pm 0,92$ and mature $11,58 \pm 0,93$ reported by (Miranda, ,2014) in his study Effects of two coatings on the quality of the papaya (

variety Tainung, whenbeing the papaya a fruit with a high degree of breath and production of etileno attains that during the storage observe a greater concentration of soluble solids, in the babaco semimaduro $5-6$ and mature $>6{ }^{\circ}$ Brixthat indicates the Norm INEN1 998:2005 Cool FruitsBabaco Requirements, indicates that the different states of maturity of the fruit observed a lower concentration of sugars to measure that advanced the process of maduration by effect of the coatings.

In the $\mathrm{pH}$ found values in $\mathrm{b}_{0}$ (semimaduro) $=4,585$ and $b_{1}$ (mature) $=4,53667$ in carambola semimadura 2, $71 \pm 0$, 33and mature 3, $44 \pm 0$, 05reportedby (Narain, , 2011) in his study physical and chemical Composition of the fruit carambola ( .) In three states of maturity, this indicates that the fruits obtained a slight increase on the percentage of $\mathrm{pH}$ to measure that advanced the maduration, in the papaya and babaco semimaduro and mature the value is upper to 5, $3 \pm 0,04$ what does reference (Miranda, ,2014) in his study Effects of two coatings on the quality of the papaya ( ) variety Tainung, observes that these fruits for being climatéricas generate greater transpiration, but thanks to the action of the coating avoids that it advance quickly the maduration by what in the $\mathrm{pH}$ keeps in lower increase.

In the $\mathrm{q}$ respecta to the acidityin (semimaduro) $=0,238083$ and $b_{1}$ (mature) $=0,310833$ in carambola semimadura $0,5 \%$ and mature $0,3 \%$ taken by (Siller-Cepeda, , 2004) in his studyQuality in fruits of carambola (

Harvested in four states of maturity, this wants to say that during the days of storage there was a minimum increase of the acidity since they kept recubriertas retardando the maturity.

In the loss of weight determined values in $b_{0}$ (semimaduro) $=7,71917$ and $b_{1}$ (mature) $=3,72167$ in the carambola, papaya and the babaco, in state semimaduro and mature the value finds underneath of $9,54 \pm 0,10$ reported by Miranda, , 2014) in his study Effects of two coatings on the quality of the papaya (Carica papaya) variety Tainung, since by means of the application of the coatings to base of polymers which creates a barrier that avoids the loss of water as well as also his deterioration.

Andn what respecta to the evolution of the colorimetric coordinates CIE-L* $\mathrm{a}^{*} \mathrm{~b}^{*}$, in the coordinate $\mathrm{L}^{*}$ (luminance) $\mathrm{a}^{*}($ semimaduro $)=45,1816$ and $b_{1}$ (mature) $=61,6478$ (see these finds underneath to 88,08 those that does reference (Camacho, , 2012) in the investigacion Determination of the colour of the exocarpio like indicator of physiological development and maturity in the guava pear (

Guava pear), usesndo technical of digital processing of images indicates that the state of maturity incide that the fruits have a tendency in the skin to clear colours in what the maturity advances.

Lto coordinate $\mathrm{a}^{*}$ (variation of red colour-green) in $b *$ (semimaduro) $=-8,78066$ and $b_{1}$ (mature) $=-8,87494$ these values find upper to $-7,76$ reported by (Camacho, 2012) , this wants to say that by effect of the coating the fruits kept in a green tonality in the storage.

Mientras that the coordinate $b^{*}$ (variation of the yellow colour-blue) $b_{0}$ (semimaduro) $=28,0883$ and $b_{1}$ (mature) $=34,5404$ these values find inferior to 52,76 in the reported by (Camacho, , 2012) in which it observes that the fruits presented a light increase of the yellow colour at the end of the storage.

\begin{tabular}{|c|c|c|c|c|c|c|c|}
\hline Factor B & Brix & PH & Acidity & Loss of weight & $\mathrm{L}^{*}$ & $\mathrm{a}^{*}$ & $\mathrm{~b}^{*}$ \\
\hline Semi Mature & 7,65 & 4,585 & 0,238083 & 7,71917 & 45,1816 & $-8,78066$ & 28,0883 \\
\hline Mature & 8,05 & 4,53667 & 0,310833 & 3,72167 & 61,6478 & $-8,87494$ & 34,5404 \\
\hline
\end{tabular}




\section{International Journal of Science and Research (IJSR) \\ ISSN (Online) : 2319-7064}

Index Copernicus Value (2015) : 78.96 | Impact Factor (2015) : 6.391

Types of coatings (Starch of yuca and Protein of soya)

In the Factor $\mathrm{C}$ (types of coating), determined values in ${ }^{\circ}$ Brix inc $_{0}$ (starch of yuca) $=7,48333$ and $c_{1}$ (protein of soya) $=8,21667$ these are inferior to $7,819^{\circ}$ Brix in what it does reference (Achipiz, , 2013) in his study Effect of coating to base of starchon the maduration of the guava ( ), in whichit observes a decrease of the degrees Brix in the fruits recubiertos with starch of yuca this can be related with the lower tax of breath of the fruits by effect of the coating.

Andn the $\mathrm{pH}$ obtained values inc $_{0}$ (almidon of yuca) $=4$, 36083 and $c_{1}$ (protein of soya) $=4,76083$ which are upper to 3, 6 die by (Andrade, , 2013) in the study Preparation and evaluation of anedible coating for the conservation postcosecha of the tomato of tree ( Cav. Sendt) This wants to say that the $\mathrm{pH}$ of the fruits presented in similar percentage since the process of maduration was slow thanks to the reaction of the coatings.

In what it concerns to acidity $c_{0}$ (almidon of yuca) $=0$, 281417 and $c_{1}$ (protein of soya) $=0,2675$ these values are underneath of 0,66 in the reported by (Andrade, , 2013) which indicates that the two types of coatings because of his protective action diminish the process of maduration in the storage.

Andnloss of weight found values in $\mathrm{c}_{0}$ (almidon of yuca) $=5$, 525 and $c_{1}$ (protein of soya) $=5,91583$ these find underneath of $7,5 \%$ in what it does reference (Andrade,
2013) since the coatings to base of polymers attain to reduce the percentage of loss of weight and generates in the coating an effective barrier to the loss of water of the fruits.

Andn what respecta to the evolution of the colorimetric coordinates CIE-L* $\mathrm{a}^{*} \mathrm{~b}^{*}$, in the coordinate $\mathrm{L}^{*}$ (luminance) in $c_{0}$ (almidon of yuca) $=44,9535$ and $c_{1}$ (protein of soya) $=61,8759$ which find underneath of 88,08 what does reference (Camacho, , 2012) in the investigacion Determination of the colour of the exocarpio like indicator of physiological development and maturity in the guava pear ( . Guava pear), using technical ofp rocesamiento digital of images, these values indicate that the coatings applied in the fruits avoid the darkening since they present luminous values.

$L^{*}$ coordinate $a^{*}$ (variation of red colour-green) in $c_{0}$ (almidon of yuca) $=-7,46414$ and $c_{1}$ (protein of soya) $=-10$, 1915 these values find upper to $-7,76$ reported by (Camacho, , 2012), these results obtain due to the fact that the coatings acted of a positive form and help to that the process of maduracion are slow, by the appreciated green tonalities in the fruits.

Lto coordinate $\mathrm{b}^{*}$ (variation of the yellow colour-blue) in $\mathrm{c}_{0}$ (almidon of yuca) $=26,3583$ and $c_{1}$ (protein of soya) $=36$, 2704 these values find inferior to 52,76 in the reported by (Camacho, , 2012) of agreement to the data obtained reflects that the coloracion yellow was low thanks to the accion of the coatings to the retardar the maduracion.

\begin{tabular}{|l|c|c|c|c|c|c|c|}
\hline & & & & & & & \\
\hline Coating (Starch of yuca) & 7,48333 & 4,36083 & 0,281417 & 5,525 & 44,9535 & $-7,46414$ & 26,3583 \\
\hline Coating (Protein of soya) & 8,21667 & 4,76083 & 0,2675 & 5,91583 & 61,8759 & $-10,1915$ & 36,2704 \\
\hline
\end{tabular}

\section{Conclusions}

The carambolas when being recubiertas con polymers like edible coatings obtained better results in the physical analyses chemists and attained that his process of maduration retarde prolonging the useful life of this fruit. The state of optimum maturity for the application of the coating is in fruits semimadura due to the fact that they obtained acceptable results regarding the analyses degrees Brix, $\mathrm{pH}$, acidity, loss of weight and colorimetry. The fruits recubiertas with starch of yuca his process of maduration was slow, this wants to say that with the help of the coating attained obtain a barrier that avoids the high transpiration and breath of the fruit. The best treatment was (Carambola*Semimadura*Starch of yuca) $\left(t o_{0} b_{0} c_{0}\right)$ since when being recubierta obtained a period of conservation of 23 days in storage with an index of maturity of $10 \%$, which compared with fruits no recubiertas that had a conservation of 9 days with an index of maturity of $18,6 \%$.

\section{References}

[1] J. Quintero, «Films and edible coatings: importance and recent tendencies in the chain hortofruticula, » TUMBAGA, vol. 1, number 5, p. 94, 2010.
[2] J. Figueroa, «edible Coatings in the conservation of the mango and avocado, and perspective, to the use of the propóleo in his, » Dialnet, vol. 3, number 2, p. 387, 2011.

[3] J. F. B. Arévalo and G. And. T. Zapata, «Edible Coatings for Foods to Base of Biodegradable Polymers, Sour Grasos and Antioxidant, " National Faculty of Agronomy Medellín, vol. 67, number 2, p. 420, 2014.

[4] H. Villada, H. It puts to bed and R. Velasco, «natural biopolymers used in biodegradable packagings, » Scielo, vol. 70, number 4, 2007.

[5] D. And. Or. Bolaños, D. Z. Camacho, J. L. H. Concha, S. To. M. Sánchez and L. P. M. Sánchez, «Effect of coating of starch of yuca modified and oil of thyme applied to the pepper (Capsicum annuum) *, » Redalyc, vol. 5, number 5, pp. 796-797, 2014.

[6] M. d. L. R. García, S. B. Bathrooms, L. L. B. Necha, And. B. Molina, I. To. Tejacal And M. EstradaCarrillo, «Antimicrobic Compounds Added in Edible Coatings for Use in Products Hortofrutícolas., ") Scielo, vol. 28, number 1, 2010.

[7] J. D. Ramírez, I. D. Aristizábal And J. I. Restrepo, «conservation of Muslim of castilla by means of the application of an edible coating of gel of mucilage of penca of sábila, » Redalyc, vol. 20, number 3, p. 173, 2013.

Volume 6 Issue 1, January 2017 
[8] J. Restrepo And I. Aristizábal, «Conservation of strawberry (Fragaria x ananassa Duch cv. Camarosa) By means of the application of edible coatings of gel mucilaginoso of penca sábila (Aloe barbadensis Miller) and wax of carnaúba., " VITAE ( magazine of the faculty of pharmaceutical chemistry), vol. 17, number 3, p. 253, 2010.

[9] To. Velásquez-Moreira and J. To. G. Beltrán, «Some recent investigations in edible coatings applied in foods., » Department of Ingenieria Quimica, Foods and Environmental, University of the Américas, Populates., vol. 5, number 12, p. 7, 2014.

[10] G. V. d. 1. Cruz, M. M. Polo, R. M. Peniche And M. R. Cárdenas, «effect of the temperature, relative humidity and type of coating on the breath of the guava, " Redalyc, vol. 2, number 2, 1998.

[11] W. V. Oviedo, «Handle of fruits and vegetables in postcosecha, behaviour fisiologico of fruits and vegetables during the postcosecha., " of Tecnologia of the handle of postcosecha of fruits and vegetables, 1987, p. 43.

[12] J. Restrepo And I. Aristizábal, «CONSERVATION OF STRAWBERRY (Fragaria $\mathrm{x}$ ananassa Duch $\mathrm{cv}$. Camarosa) BY MEANS OF THE APPLICATION OF EDIBLE COATINGS OF GEL MUCILAGINOSO OF PENCA SÁBILA (Aloe barbadensis Miller) And WAX OF CARNAÚBA, » Scielo, vol. 17, number 3, p. 255, 2010.

[13] To. Miranda, To. Alvis and G. Arrazola, «Effects of two coatings on the quality of the papaya (Carica papaya) variety tainung, » Agricultural Subjects, vol. 19, number 1, p. 7, 2014.

[14] J. K. c. Camacho, N. And. C. Crag and N. G. Guzmán, «Determination of the colour of the exocarpio like indicator of physiological development and maturity in the guava pear (Psidium guajava cv. Guava pear), using technical of digital processing of images, " Magazine EIA, vol. 10, number 19, p. 83, 2012.

[15] J. Andrade, D. It puts to bed, M. Bucheli And G. Moon, «Preparation and evaluation of an edible coating for the conservation postcosecha of the tomato of tree Cyphomandra betacea Cav. Sendt, » Dialnet, vol. 30, number 2, pp. 67, 68, 2013.

[16] S. Achipiz, To. Castle, S. Mosquera, J. Holes and D. Navia, «Effect of coating to base of starch on the maduration of the guava (Psidium guajava), » Scielo, vol. 11, 2013.

[17] P. Miranda, G. Cárdenas, D. López and To. V. LaraSagahon, «Behaviour of films of Quitosán composed in a model of storage of avocado, » Redalyc, vol. 47, number 4, 2004. 